tions between leaf and soil mineral concentrations and ginsenoside contents in american ginseng. HortScience 34:85-87.

Li, T.S.C., G. Mazza, A.C. Cottrell, and L. Gao. 1996. Ginsenosides in roots and leaves of american ginseng. J. Agr. Food Chem. 44:717-720.

Li, T.S.C. and L.C.H. Wang. 1998. Physiological components and health effects of ginseng, echinacea, and sea buckthorn, $\mathrm{p}$. 329-356. In: G. Mazza (ed.). Functional foods: Biochemical and processing aspects. Technomic Publ., Lancaster, Pa.

Liu, N.N. 1988. Cultural methods of ginseng (in Chinese). Wu-Chou Publ. Co., Taipei, Taiwan.

Ma, Y.C. 1995. A comparative evaluation of ginsenosides in commercial ginseng products and tissue culture samples using HPLC. J. Herbs, Spices and Medicinal Plants 3:41-50.

Reynolds, L.B. 1998. Effects of harvest date on some chemical and physical characteristics of american ginseng (Panax quinquefolus L.). J. Herbs Spices and Medicinal Plants 6:63-69.

SAS Institute. 1990. SAS/STAT user's guide, vers. $6,4^{\text {th }}$ ed. SAS Inst., Cary, N.C.

Schwalb, P. and W. Feucht. 1999. Changes in the concentration of phenolic substances in the bark during the annual development of the cherry tree (Prunus avium L.). Adv. Hort. Sci. 13:71-75.

Soldati, F. and O. Tanaka. 1984. Panax ginseng: Relation between age of plant and content of ginsenosides. Planta Medica 50:351-352.

Xu, K. and K.Z. Xu. 1994. Study on variability of specific leaf weight in Panax ginseng (in Chinese). J. Jilin Agr. Univ. 16:39-42. (CAB Abstracts on CD-ROM 1996-1998/07).

\section{Using Paclobutrazol to Control Height of Poinsettia 'Freedom'}

\author{
Genhua Niu, Royal Heins, ${ }^{1}$ \\ and Will Carlson
}

Additional IndeX words. bract area, plant growth retardant, stem elongation, Euphorbia pulcherrima

Summary. Late-season height control of poinsettia (Euphorbia pulcherrima) is difficult since most chemical growth retardants adversely reduce bract size when applied after first bract color. Paclobutrazol (Bonzi) controls stem elongation late in poinsettia crop development but can excessively reduce bract size if improperly applied. Two experiments were conducted to quantify how paclobutrazol application influenced height and bract area of 'Freedom' poinsettia. In the first experiment, paclobutrazol was applied at $1 \mathrm{mg} \cdot \mathrm{L}^{-1}$ $(\mathrm{ppm})$ in $118-\mathrm{mL}(4.0-\mathrm{fl} \mathrm{oz})$ volumes per pot [(a.i.) $0.12 \mathrm{mg} /$ pot $(28,350$ $\mathrm{mg}=1.0 \mathrm{oz})]$ as a drench to a new group of plants weekly from the initiation of short days until 1 week before anthesis. Maximum reduction in height and bract area was obtained when paclobutrazol was applied immediately after short days, and the response to paclobutrazol decreased as application time was increasingly delayed toward anthesis. In the second experiment, paclobutrazol was applied weekly after first bract color as either a drench or subapplication at various concentrations. Plant height and bract area were reduced by $23 \%$ when $2 \mathrm{mg} \cdot \mathrm{L}^{-1}$ [(a.i.) $0.24 \mathrm{mg} /$ pot) paclobutrazol was applied through subapplication at first color. The effects of paclobutrazol on height and bract area reduction decreased as application time was progressively delayed. Concentrations lower than 1

Department of Horticulture, Michigan State Univer sity, East Lansing, MI 48824-1325.

The authors wish to acknowledge the Michigan Agricultural Experiment Station and funding provided from GREEEN Project GR00-049. We also thank Uniroyal Chemical Co. for partial funding of this project.

${ }^{1}$ Author to whom correspondence should be addressed; e-mail heins@msu.edu. $\mathrm{mg} \cdot \mathrm{L}^{-1}$ had no significant effect on height or bract area reduction, regardless of application time or method. Generally, the reduction in height and bract area was larger when paclobutrazol was applied through subapplication. The combined results from both experiments indicate that paclobutrazol drench applications after flower initiation concomitantly reduce plant height (internode extension) and bract area. Therefore, drench applications should be delayed as long as possible to limit reduction in bract size.

$\mathrm{H}$ eight control is difficult for poinsettia producers. Commercial growers must produce plants that meet the market height specifications; otherwise, plants will have a lower value, be more expensive to ship, or be totally unsaleable. Without some method of height control, poinsettias generally grow too tall in a greenhouse. Factors that contribute to tall plants include genetics, high plant density, positive DIF (difference between day and night temperatures), and excessive vegetative growth before the start of short-day flower initiation (Fisher and Heins, 1997). Traditionally, growth-retardant chemicals are applied intermittently for height control from planting until the poinsettia shows first bract color. Although growth retardant chemicals applied after first color effectively reduce stem elongation, they also reduce bract size and may delay bract development (Hartley, 1992). The reduction in bract size can be substantial. Plants with small bracts are less attractive, and if bracts are excessively small, plants may not be saleable.

'Freedom' was introduced to the poinsettia market in the early 1990s and accounts for about $55 \%$ of the red poinsettias grown in North America (Barrett and Wieland, 1997). This cultivar tends to elongate slowly when plant density and leaf area index (LAI) are low but elongates rapidly when the crop forms a solid leaf canopy and LAI is high. Under typical crop culture, the crop forms a solid canopy in late October and early November after first color. Poinsettia shoots can then elongate rapidly to quickly exceed final height specifications (Faust and Klein, 1998).

The rapid elongation in late October and early November is commonly called late stretch. The term is appropriate because the elongation occurs late in crop development when stem 
elongation should be decreasing. Late stretch is an especially difficult problem for growers since most growth retardant chemicals cannot be safely applied in late October and early November without adversely affecting bract size. Paclobutrazol (Bonzi; Uniroyal Chemical Co., Middlebury, Conn.) and ancymidol (A-Rest; SePRO Corp., Carmel, Ind.) are the only growth-retarding chemicals that have been used with some success to control late stretch of poinsettia (Hammer, 1996; Moore, 1996). Faust et al. (2001) reported that paclobutrazol applied at the end of October or early November have the least risk for negatively affecting bract size while still reducing stem elongation of 'Freedom Red' poinsettia.

The effectiveness of growth-retardant chemicals depends not only on timing of application but also on concentration, application method (subapplication or drench), and growing conditions such as temperature, light, and humidity. Application of paclobutrazol as a drench is recommended for control of late stretch and spray applications are not typically recommended after the appearance of first bract color. In a traditional drench, the chemical solution is applied to the surface of a pot. It takes some time to move the active ingredient to the lower parts of the medium where most roots grow. Thus, the effect of the chemicals is stronger when they are applied through subapplication (Barrett, 1999). Therefore, application rates should also be based on the application method to avoid under- or overapplications.

The intent of this research was to develop recommendations for proper paclobutrazol use for control of late stretch in poinsettia. The objective was to characterize poinsettia response to paclobutrazol applied at various concentrations and various times, from initiation of short days or first color to anthesis, using different delivery methods to the medium.

\section{Materials and methods Application time (Expt. 1)}

General culture. Unrooted cuttings were obtained from a commercial producer on 18 May 2000. Upon arrival, cuttings were propagated in $10-\mathrm{cm}(4$-inch) round pots [470$\mathrm{mL}(0.124$-gal) volume] containing peat-perlite mix (Sure-Mix; Michigan Grower Products, Galesburg, Mich.). Air and medium temperatures in the propagation house were maintained at $23 \pm 2^{\circ} \mathrm{C}\left(73 \pm 3^{\circ} \mathrm{F}\right)$ and $26 \pm 3^{\circ} \mathrm{C}(79$ $\pm 3{ }^{\circ} \mathrm{F}$ ), respectively. Misting was provided according to irradiance. Rooted plants were moved to another greenhouse section maintained at $24 \pm 2{ }^{\circ} \mathrm{C}$ $\left(75 \pm 3^{\circ} \mathrm{F}\right)$ on 7 June 2000 under natural daylength. The plants were transplanted from $10-\mathrm{cm}$ pots to $15-$ $\mathrm{cm}$ (6-inch) pots [1.3-L (0.343-gal) volume] on 18 June 2000 and placed at a density of 11.1 plants $/ \mathrm{m}^{2}$ (1 plant/ $\left.\mathrm{ft}^{2}\right)[30 \times 30 \mathrm{~cm}(1 \times 1 \mathrm{ft})]$. Plants were pinched to six nodes 1 week after transplanting. A short photoperiod was initiated on 12 July by pulling black cloth at $1700 \mathrm{HR}$ and opening it at 0800 HR. Air temperature of the glass greenhouse was maintained at $20 \pm 2$ ${ }^{\circ} \mathrm{C}\left(68 \pm 4{ }^{\circ} \mathrm{F}\right.$, actual temperatures $)$ by using pad-and-fan cooling system under natural sunlight. Plants were topwatered as necessary with a nutrient solution of well water acidified with sulfuric acid $\left(\mathrm{H}_{2} \mathrm{SO}_{4}\right)$ to a titratable alkalinity of lime calcitic $\left(\mathrm{CaCO}_{3}\right)$ at $130 \mathrm{mg} \cdot \mathrm{L}^{-1}$ and water soluble fertilizer containing macronutrients of nitrogen, phosphorus, potassium, and calcium at $125,12,125$, and $13 \mathrm{mg} \cdot \mathrm{L}^{-1}$, respectively (MSU Special; Greencare Fertilizers, Chicago, Ill.).

Paclobutrazol application. Plants were randomly assigned to eight groups (including control plants), each containing 10 plants, for paclobutrazol application treatment over time. Paclobutrazol was applied as a drench at 1 $\mathrm{mg} \cdot \mathrm{L}^{-1}$ in $118 \mathrm{~mL}(4.0 \mathrm{fl} \mathrm{oz})$ volumes per pot to an assigned group every week

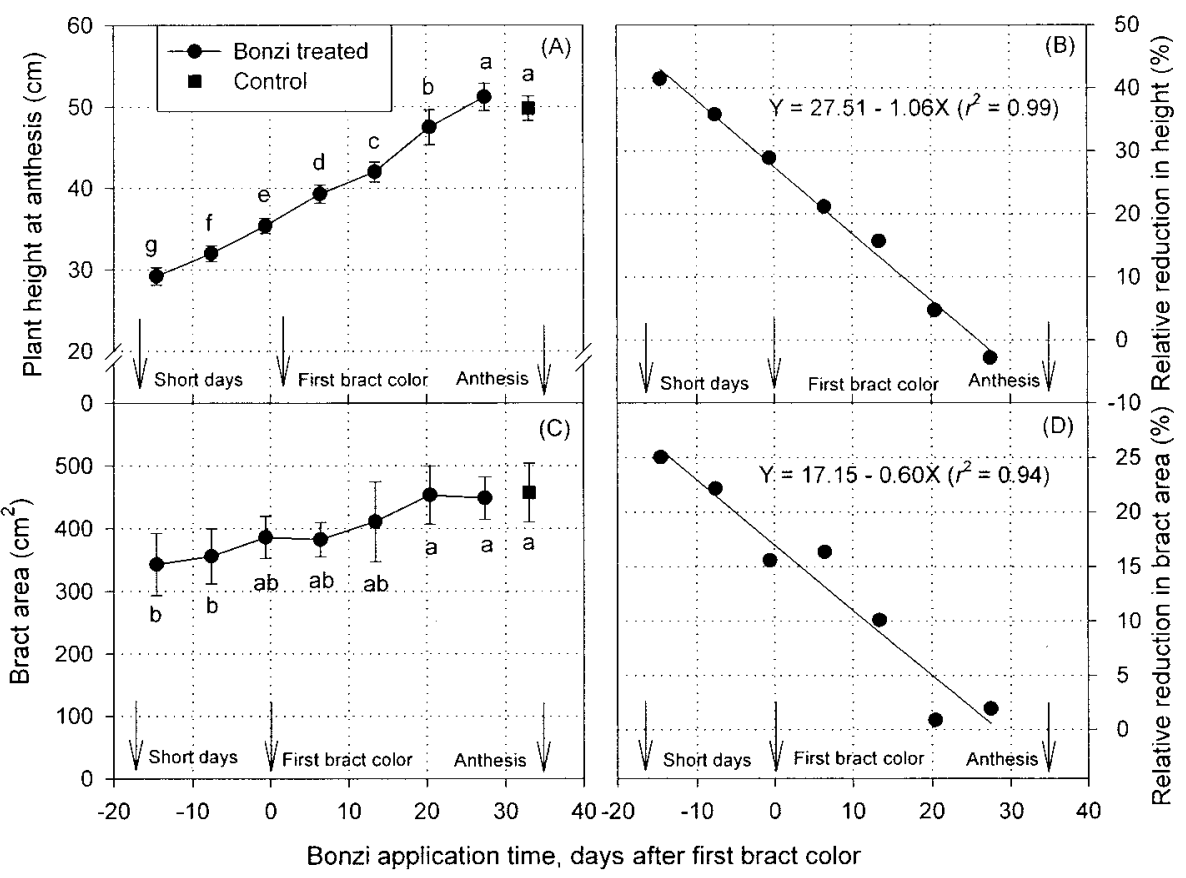

(7 weeks total) between start of short days and flower, and the first drench was applied on 14 July. Each group received one paclobutrazol application. The group that was not treated with paclobutrazol was treated as the control.

Data collection and analysis. Height of all plants was recorded weekly. Dates of first bract color and anthesis were recorded. At anthesis, length and width of bract leaves (six bract leaves at the base of the inflorescence and three below) were recorded for two shoots per plant. Bract area was estimated by multiplying the length of each bract leaf by its width and adding all the bract leaf measurements of the shoot. Relative height or bract area reduction compared with that of control plants was calculated and plotted against paclobutrazol application time as days after first bract color, which was calculated by subtracting the date of first bract color from application dates. Means of each treatment were compared by Student-Newman-Keuls' multiple range test by using Statistical Analysis System's GLM PROC (SAS Institute, Cary, N.C.).

Fig. 1. Effect of a $1 \mathrm{mg} \cdot \mathrm{L}^{-1}$ ( $\left.\mathrm{ppm}\right)$ [(a.i.) $0.12 \mathrm{mg} /$ pot] paclobutrazol (Bonzi) drench on plant height, bract area, and relative reduction in height and bract area of 'Freedom' poinsettia plants. Different letters represent mean separation within each treatment by Student-Newman-Keuls multiple range test $(P=0.05)$. Vertical error bars represent $95 \%$

confidence intervals. 


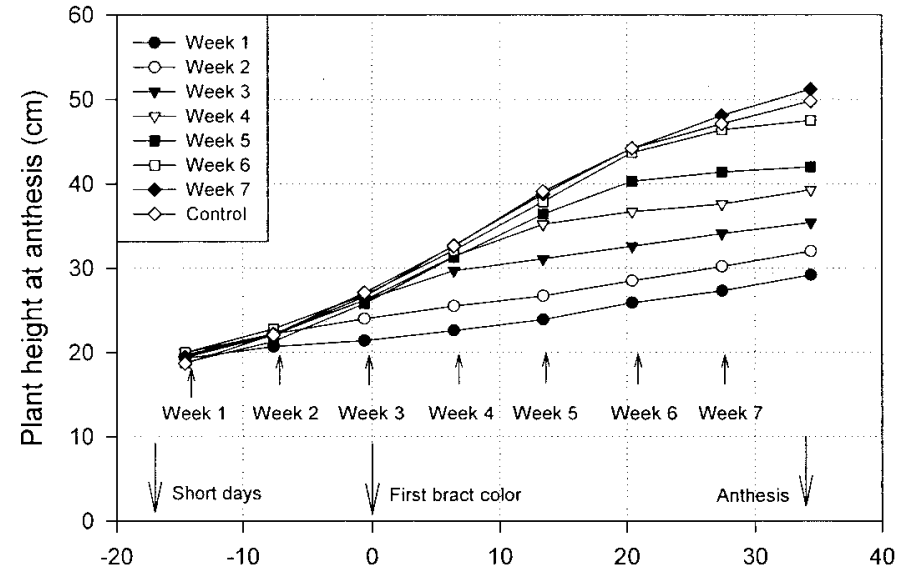

Bonzi application time, days after first bract color (five levels), application concentration (four levels), and application method (two levels). Each group (10 plants) received only one paclobutrazol application. Plants treated with paclobutrazol via subapplication were always irrigated by subirrigation through the end of the experiment. A20-cm

Fig. 2. Time course of plant height of 'Freedom' poinsettia as affected by paclobutrazol (Bonzi) applied weekly (seven times) as a drench at various times from the initiation of short days to 1 week before anthesis.

\section{Application time, concentration, and method (Expt. 2)}

Rooted cuttings of 'Freedom' poinsettia were received in $15-\mathrm{cm}$ round pots from a commercial grower on 21 Aug. 2000. Upon arrival, rooted cuttings were placed in a greenhouse maintained at $20 \pm 2{ }^{\circ} \mathrm{C}$ under natural daylength. Plants were pinched to leave six nodes on 28 Aug. Plants were topwatered as necessary until the start of paclobutrazol application by using the same kind of nutrient solution used in Expt. 1.

Plants were randomly grouped and assigned a paclobutrazol application time (once per week for 5 weeks from shortly after first bract color to 1 week before anthesis), concentration $[0.25,0.5,1.0$, or $2 \mathrm{mg} \cdot \mathrm{L}^{-1}$ (a.i.) $0.03,0.06,0.12$, or $0.24 \mathrm{mg} /$ pot, respectively], and method (drench or subapplication). The experiment was a three-way factorial design with main factors of application time

Fig. 3. Effect of paclobutrazol (Bonzi) application as a drench or subapplication at 1 or $2 \mathrm{mg} \cdot \mathrm{L}^{-1}$ (ppm) [(a.i.) 0.12 or $0.24 \mathrm{mg} /$ pot] on relative height increase from first bract color to anthesis $(A, B, C$, and $D$ ) and height reduction as compared with control plants $(E$ and $F$ ) of 'Freedom' poinsettia. Different letters represent mean separation within each treatment by StudentNewman-Keuls' multiple range test $(P=0.05)$. Vertical error bars represent $95 \%$ confidence intervals. (8-inch) round plastic tray was used underneath the 6-inch round pot for paclobutrazol application and subirrigation. Plants treated with paclobutrazol as a drench were continually top-watered as necessary throughout the experimental period. Application volume was $118 \mathrm{~mL} /$ pot for both application methods and all concentrations.

Dates of first bract color and anthesis were recorded. Height of all plants was recorded weekly. At anthesis, bract area per shoot (three bracts at the base of the inflorescence and five below), two shoots per plant, was measured by using a leaf area meter (LI-3100; LICOR, Lincoln, Neb.). Data were analyzed as they were in Expt. 1.

\section{Results}

EXPERIMENT 1. Plants showed first bract color on 28 July 2000 (average), $17 \mathrm{~d}$ after initiation of short days, and reached anthesis on 1 Sept. 2000, $35 \mathrm{~d}$ after first bract color and $52 \mathrm{~d}$ after the start of short days. There were no significant differences in time to first bract color or anthesis among treatments.

Plant height at anthesis increased as paclobutrazol application time was increasingly delayed from initiation of short days to anthesis (Fig. 1A). Height of the plants treated with paclobutrazol one week before anthesis was not significantly different from that of control plants. The relative reduction in height decreased linearly as paclobutrazol application times were increasingly delayed from initiation of short days to anthesis (Fig. 1B).

Bract area of the plants treated with paclobutrazol in the first and second weeks after the initiation of short days was significantly different from that of control plants and those treated with paclobutrazol 1 or 2 weeks before anthesis (Fig. 1C). Bract area was $20 \%$ smaller in plants treated with

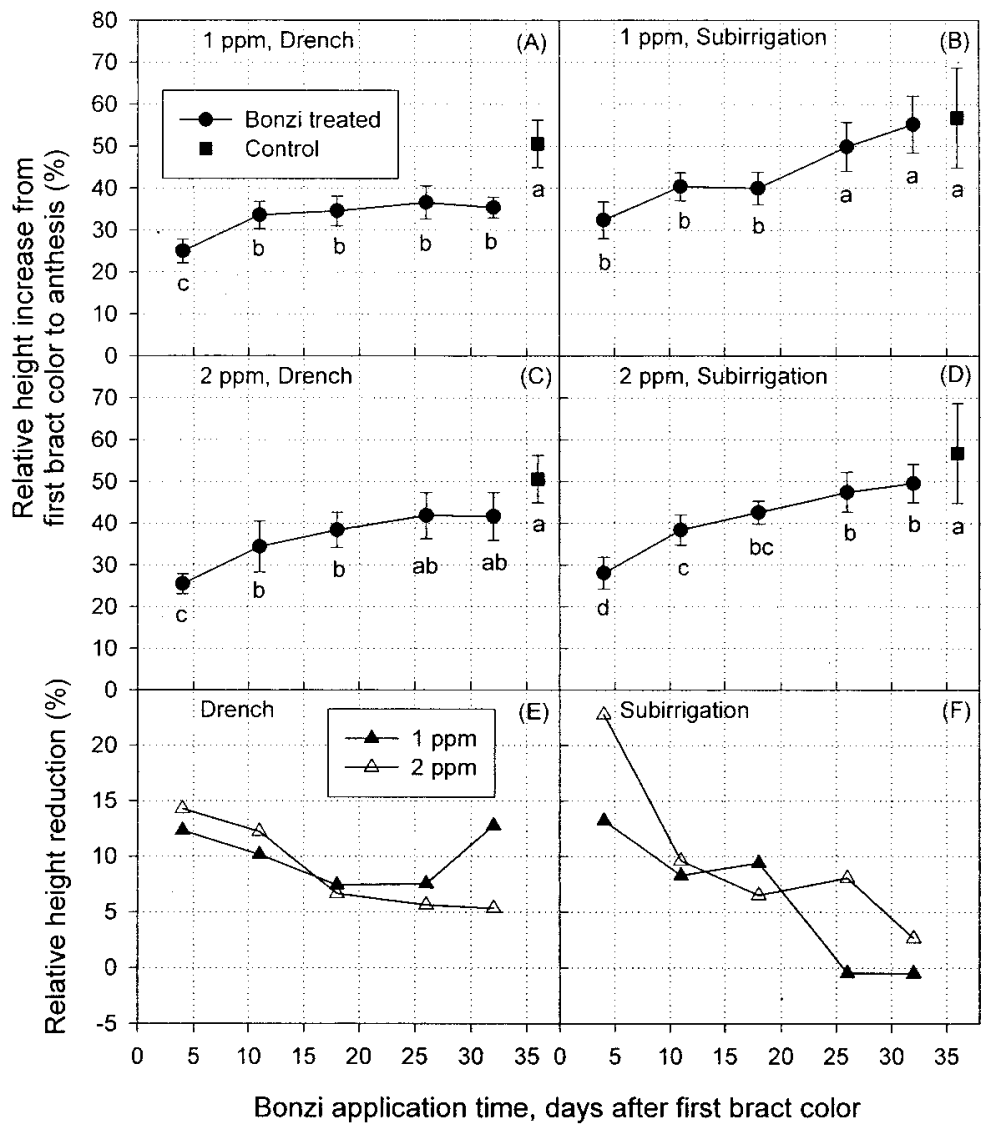




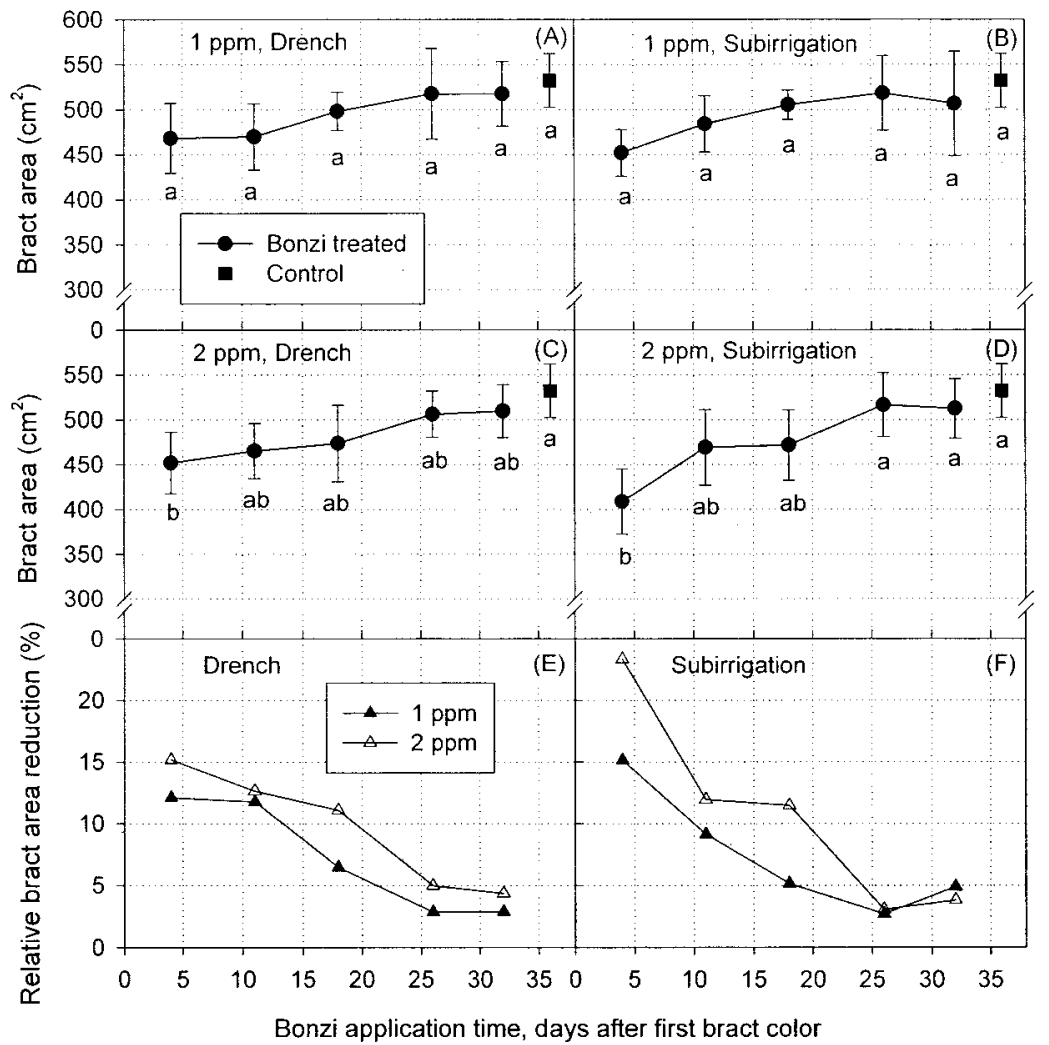

Fig. 4. Effect of paclobutrazol (Bonzi) application as a drench or subapplication at 1 or $2 \mathrm{mg} \cdot \mathrm{L}^{-1}$ (ppm) [(a.i.) 0.12 or $0.24 \mathrm{mg} / \mathrm{pot}$ ] on bract area at anthesis $(A, B, C$, and $D)$ and bract area reduction compared with control plants ( $E$ and $F$ ) of 'Freedom' poinsettia. Different letters represent mean separation within each treatment by StudentNewman-Keuls' multiple range test $(P=0.05)$. Vertical error bars represent $95 \%$ confidence intervals.

paclobutrazol the first and second week after the initiation of short days (Fig. 1D). The reduction in bract area was less than $5 \%$ when paclobutrazol was applied 1 or 2 weeks before anthesis (or 3 weeks after first bract color).

Plant height responded visibly to paclobutrazol within 2 weeks after paclobutrazol application (Fig. 2). Paclobutrazol had a minimal effect on height when applied late in the season (1 or 2 weeks before anthesis).

EXPERIMENT 2. Plants showed first color on 12 Oct. 2000 (average) and reached anthesis on 23 Nov. 2000, $42 \mathrm{~d}$ after first bract color. There were no substantial differences in time to first bract color and anthesis among treatments.

Plants treated with paclobutrazol at low concentrations of $0.25 \mathrm{mg} \cdot \mathrm{L}^{-1}$ and $0.5 \mathrm{mg} \cdot \mathrm{L}^{-1}$ did not have signifi- cantly reduced height and bract area, regardless of application method and time. Therefore, results of these treatments are not shown in figures. Since there was some variation in initial plant height, relative height increase from first bract color to anthesis in percentage instead of the absolute height or its increase is shown (Fig. 3A, B, C, and D).

Relative height increase from first bract color to anthesis of plants treated with paclobutrazol during the 3 weeks following first bract color was significantly less than that of control plants at $\mathrm{l}$ and $2 \mathrm{mg} \cdot \mathrm{L}^{-1}$ paclobutrazol applied as a top drench or subapplication (Fig. 3A, $\mathrm{B}, \mathrm{C}$, and $\mathrm{D})$. The maximum height reduction was about $15 \%$ and $23 \%$ for drench and subapplication treatments (Fig. 3E and F), respectively.

Bract area of all plants treated with paclobutrazol at $\mathrm{l} \mathrm{mg} \cdot \mathrm{L}^{-1}$ was not significantly different from that of control plants (Fig. 4A and B). The bract areas of plants treated immediately after first bract color with paclobutrazol at $2 \mathrm{mg} \cdot \mathrm{L}^{-1}$ as either a drench or subapplication were significantly different from that of control plants (Fig. 4C and D). Paclobutrazol applied at least a week after first bract color did not significantly reduce bract area of the plants, regardless of application method and concentration. The maximum relative bract reductions of plants treated with paclobutrazol were $15 \%$ and $23 \%$ when paclobutrazol was applied at $2 \mathrm{mg} \cdot \mathrm{L}^{-1}$ as a drench and subapplication, respectively (Fig. 4E and $\mathrm{F}$ ). The relative bract area reduction was $5 \%$ or less when paclobutrazol was applied at least 3 weeks after first bract color.

\section{Discussion}

Height and bract area were reduced the most when paclobutrazol was applied immediately after initiation of short days, and the reduction decreased as application days were increasingly delayed toward anthesis. Height reduction was $30 \%$ to $40 \%$ when paclobutrazol was applied between short days and first bract color. Application time's effect on height and bract reduction in Expt. 2 generally matched that in Expt. 1, although variations were larger in Expt. 2. Paclobutrazol applied later than the third week after first bract color did not substantially reduce plant height and bract area, regardless of application method and concentration. Concentrations lower than $1 \mathrm{mg} \cdot \mathrm{L}^{-1}$ did not influence height and bract area reduction, irrespective of application time and method. Height and bract area were reduced more when paclobutrazol was applied through subapplication at 2 rather than $1 \mathrm{mg} \cdot \mathrm{L}^{-1}$. However, there was only a slight difference in height and bract area reduction between the two application concentrations when paclobutrazol was applied as a drench. Subapplication generally had more effect on height and bract area reduction. This is because active ingredients in a subapplication can reach quickly the growing roots, which are distributed in the lower part of the pot. When a drench is applied, the chemical solution is applied to the surface of the media. It takes some time to move the active ingredient to the growing roots. Thus, effect of the chemicals is stronger when applied through subapplication than when applied as a traditional drench to the top of the media.

Cox (2000) applied paclobutrazol as a drench on 'Red Sails' poinsettia plants during initial bract expansion and coloring and reported that height reductions were unaffected by the number of paclobutrazol applications, the concentration $\left(1,2\right.$, or $\left.3 \mathrm{mg} \cdot \mathrm{L}^{-1}\right)$, and the drench volume $(3,4$, or $5 \mathrm{fl} \mathrm{oz} /$ pot). Some bracts distorted when paclobutrazol was applied at 0.36 to 
$0.45 \mathrm{mg} /$ pot. Plant height was reduced acceptably without reduction in bract size and without bract distortion by applying paclobutrazol as a drench at $0.24 \mathrm{mg}$ /pot or less in one application.

Combining the results from the two experiments, we conclude that application time is critical to control late stretch without significantly reducing bract area. Plant height and bract area were reduced excessively when paclobutrazol was applied anytime from start of short days to first bract color. Plant height was acceptably reduced without statistically significant reduction in bract area when paclobutrazol was applied at $1 \mathrm{mg} \cdot \mathrm{L}^{-1}$ as a drench $\mathrm{l}$ or 2 weeks after first bract color. Paclobutrazol had a larger effect when applied as a subapplication. Our study indicated that application concentrations lower than $1 \mathrm{mg} \cdot \mathrm{L}^{-1}$ were inadequate, and concentrations $>2 \mathrm{mg} \cdot \mathrm{L}^{-1}$ were unnecessary.

\section{Literature cited}

Barrett, J. 1999. Bottoms up with growth regulators. Greenhouse Product News 9(9):32-33.

Barrett, J. and C. Wieland. 1997. Improve the quality of your poinsettias. Greenhouse Product News 7(8):14-17.

Cox, D. 2000. Late season application of paclobutrazol to control stretch of poinsettia. S.E. Floricult. 10(5):18-20.

Faust, J.E. and R. Klein. 1998. The five factors that contribute to late-season stretch in poinsettias and how to apply growth regulators to compensate for them. Greenhouse Product News 8(10):19-22.

Faust, J.E., P.C. Korczynski, and R. Klein. 2001. Effects of paclobutrazol drench application date on poinsettia height and flowering. HortTechnology 11(4):557560 .

Fisher, P. and R. Heins. 1997. Height control-From pinch to first color. Greenhouse Growers 15(10):81-82.

Hammer, P.A. 1996. Poinsettia primer. GrowerTalks 59(14):42, 44, 46-50.

Hartley, D.E. 1992. Poinsettias, p. 305331. In: R. Larson (ed.). Introduction to floriculture. $2^{\text {nd }}$ ed. Academic Press, San Diego, Calif.

Moore, S.R. 1996. Late growth regulator tips. GrowerTalks 60(7):52.
Effects of

Paclobutrazol and Chlormequat on Growth and Flowering of Lavender

\section{Papageorgiou, ${ }^{1}$ \\ P. Giaglaras, ${ }^{2}$ and E. Maloupa ${ }^{3}$}

Additional InDeX wORDs. growth retardants, greenhouse, pot plants, Lavandula stoechas

Summary. Growth retardants allowed production of more uniform, compact, flowering plants for commercial use of lavender (Lavandula stoechas). Paclobutrazol at 200, 400 and 600 $\mathrm{mg} \cdot \mathrm{L}^{-1}(\mathrm{ppm})$ was sprayed in a single or double application. Chlormequat was applied at 4000, 6000 and 8000 $\mathrm{mg} \cdot \mathrm{L}^{-1}$ in single, double or triple spray applications repeated every 13 days. Paclobutrazol reduced lateral shoot elongation and plant height, increased the number of nodes within lateral shoots, but delayed time to anthesis. In contrast, chlormequat reduced plant height with no effect on flowering. Paclobutrazol potentially may be used commercially on lavender at rates of 200 to $400 \mathrm{mg} \cdot \mathrm{L}^{-1}$ in single or double applications. The same result may be achieved with chlormequat by using 4000 to 6000 $\mathrm{mg} \cdot \mathrm{L}^{-1}$ in three or more applications.

$\mathrm{T}$ he demand for wild plant species native to Mediterranean regions is increasing as consumers ask for innovative and

This paper is a portion of a MSc thesis submitted by I Papageorgiou. The experimental part was executed at the Agricultural Research Centre of Macedonia and Thrace and financed by the Mediterranean Agronomic Institute of Chania (MAICH) member of the International Centre of Advanced Mediterranean Agronomic Studies (ICAMAS)

${ }^{1}$ National Agricultural Research Foundation, Agricultural Research Centre of Macedonia \& Thrace, Thermi 57001, Greece.

${ }^{2}$ University of Thessaly, School of Agronomy, Crop and Animal Production, Laboratory of Agricultura Constructions and Environmental Control, Odos Fytokou, Nea Ionia Magnesias, GR-38446, Greece.

${ }^{3}$ National Agricultural Research Foundation, Agricultural Research Centre of Macedonia \& Thrace, Therm 57001, Greece. ecologically diverse products. The commercial availability of such species is limited, mainly because the growing techniques for large-scale production are still under development. Lavender is a small perennial shrub that is native to many Mediterranean regions (Herrera, 1991; Kokkalou, 1988; Scroubis, 1985). It has a potential as a flowering pot plant if the uneven vegetative growth and flowering can be controlled.

Chlormequat and paclobutrazol are two commercially available growth regulators known to reduce shoot elongation and plant height and to cause uniform and earlier flowering of ornamental plants (Barett et al., 1994; Carpender and Carlson, 1970; Goulston and Shearing, 1985; Rathore et al., 1981; Sanderson et al., 1988; Tezuka et al., 1989). There have been many studies of their effects on ornamental plant growth and development (Cox and Keever, 1988; Hagiladi and Watad, 1992; Rathore etal., 1981; Tayama and Kuack, 1983; Wilkinson and Richards, 1987, 1988, 1991); however, their application on lavender has not been tested. This study was conducted to investigate the potential of the use of chlormequat and paclobutrazol to control the length and the number of nodes of the shoots and the height and flowering of lavender plants.

\section{Materials and methods}

Cultural practices. The experiment was carried out from November to May at Thessaloniki in northern Greece. Rooted apical stem cuttings were transplanted in $5.5-\mathrm{L}(1.45$-gal $)$ pots containing a 3 gravel : 3 Lithuanian peatmoss : 2 sand mixture. The pots were placed on bottom heated benches in a double-plastic greenhouse at a density of 16 plants $/ \mathrm{m}^{2}$ of bench area (1.5 plants $\left./ \mathrm{ft}^{2}\right)$. Air temperature in the greenhouse was maintained between 16 and $25^{\circ} \mathrm{C}\left(60.8\right.$ and $\left.77.0^{\circ} \mathrm{F}\right)$ using heating and fan and pad cooling. After a 10-d acclimation, the plants were pinched to five nodes.

Treatments. The treatments started $3 \mathrm{~d}$ after pinching and consisted of one or two paclobutrazol applications at 200,400 or $600 \mathrm{mg} \cdot \mathrm{L}^{-1}$ and one, two or three chlormequat applications at 4000,6000 and $8000 \mathrm{mg} \cdot \mathrm{L}^{-1}$. The spraying solution also contained a surfactant [Tween $20(0.1 \% \mathrm{v} / \mathrm{v})$; ICI Americas, Wilmington, Del.] and was applied at a rate of $192 \mathrm{~mL} \cdot \mathrm{m}^{-2}(0.6 \mathrm{fl}$ $\left.\mathrm{oz} / \mathrm{ft}^{2}\right)$. Multiple applications were 